\title{
Contamination pathways of spore-forming bacteria in a vegetable cannery
}

\author{
Loïc Durand ${ }^{a}$, Stella Planchon ${ }^{a}$, Marie-Hélène Guinebretiere ${ }^{b, c}$, Stéphane André ${ }^{a}$, \\ Frédéric Carlin ${ }^{\text {b,c }}$, Fabienne Remize ${ }^{\mathrm{a}, *, 1}$ \\ a CTCPA, Unité d'Expertise dans la Maitrise du Risque Industriel en Themorésistants Sporulés, F-84911 Avignon, France \\ b INRA, UMR408, Sécurité et Qualité des Produits d'Origine Végétale, F-84000 Avignon, France \\ c Avignon Université, UMR408, Sécurité et Qualité des Produits d'Origine Végétale, F-84000 Avignon, France
}

\begin{abstract}
A B S T R A C T
Spoilage of low-acid canned food during prolonged storage at high temperatures is caused by heat resistant thermophilic spores of strict or facultative bacteria. Here, we performed a bacterial survey over two consecutive years on the processing line of a French company manufacturing canned mixed green peas and carrots. In total, 341 samples were collected, including raw vegetables, green peas and carrots at different steps of processing, cover brine, and process environment samples. Thermophilic and highly-heat-resistant thermophilic spores growing anaerobically were counted. During vegetable preparation, anaerobic spore counts were significantly decreased, and tended to remain unchanged further downstream in the process. Large variation of spore levels in products immediately before the sterilization process could be explained by occasionally high spore levels on surfaces and in debris of vegetable combined with long residence times in conditions suitable for growth and sporulation. Vegetable processing was also associated with an increase in the prevalence of highly-heat-resistant species, probably due to cross-contamination of peas via blanching water. Geobacillus stearothermophilus M13-PCR genotypic profiling on 112 isolates determined 23 profile-types and confirmed process-driven cross-contamination. Taken together, these findings clarify the scheme of contamination pathway by thermophilic spore-forming bacteria in a vegetable cannery.
\end{abstract}

\section{Introduction}

Sealed and sterilized canned vegetables remain microbiologically stable for years at ambient temperature as the heat process inactivates mesophilic microorganisms. Spoilage in low-acid $(\mathrm{pH}>4.5)$ canned vegetables occurs mainly at high incubation temperatures $\left(>40^{\circ} \mathrm{C}\right)$ and is caused by the survival and further multiplication of thermophilic spore-forming bacteria. These bacteria are not known to be pathogenic to humans but are considered an industrial risk that warrants proper control by canning industries. For instance, the stability testing of canned foods after 7-day incubation at $55{ }^{\circ} \mathrm{C}$ (French standard NF V08-408: AFNOR, 1997) is used for detection of a lack of hygiene during fabrication and as a recommendation for export to high-temperature climate zones in line with EU regulations on safe and wholesome food in trading. The percent non-stability of canned green beans recorded for instance by the French canning industry over a 10 year period was close to $1.5 \%$ (Rigaux et al., 2014). Geobacillus stearothermophilus,

\footnotetext{
* Corresponding author at: Université de La Réunion, UMR95, QualiSud - Démarche intégrée pour l'obtention d'aliments de qualité, ESIROI, Parc Technologique Universitaire, 2 rue Joseph Wetzell, F-97490 Sainte-Clotilde, France. Tel.: +33262 262483343.

E-mail address: fabienneremize@univ-reunion.fr (F. Remize).

1 Present address: Université de La Réunion, UMR95 QualiSud, ESIROI, Parc Technologique Universitaire, 2 rue Joseph Wetzell, F-97490 Sainte-Clotilde, France.
}

Moorella thermoacetica/thermoautotrophica and Thermoanaerobacterium spp. are regularly identified as the most common causes of low-acid spoilage in canned foods, including canned vegetables, representing up to $75 \%$ of the species responsible for non-stability at $55^{\circ} \mathrm{C}$ (André et al., 2013; Ashton and Bernard, 1992; Carlier et al., 2006; Carlier and Bedora-Faure, 2006; Dotzauer et al., 2002). These three bacteria share high heat resistance, with D-values (decimal reduction times) at $121{ }^{\circ} \mathrm{C}$ greater than $1 \mathrm{~min}$ for $\mathrm{G}$. stearothermophilus in most instances and up to $111 \mathrm{~min}$ for $M$. thermoacetica (André et al., 2013; Byrer et al., 2000; Matsuda et al., 1982). Other moderately thermophilic bacteria such as Bacillus coagulans, Bacillus licheniformis, Anoxybacillus spp., Paenibacillus spp., Thermoanaerobacter spp. and Clostridium thermobutyricum/thermopalmarium that are able to survive heat treatment at temperatures over $100{ }^{\circ} \mathrm{C}$ for $10 \mathrm{~min}$ have also been identified as canned food spoilage microorganisms (André et al., 2013; Feig and Stersky, 1981; Raso et al., 1995).

Food processing facilities are exposed to a range of contamination sources (Carlin, 2011). Soil and natural environments are reservoirs of spore-forming bacteria (Groenewald et al., 2009; Guinebretiere and Nguyen-The, 2003; Logan and De Vos, 2009; Zeigler, 2014). Spore contamination into food processing facilities is vectored by soil dust in open areas, adhesion to unprocessed food material, or carriage by employees (Groenewald et al., 2009; Sevenier et al., 2012). The process of canning vegetables combines several operations resulting in contamination with 
micro-organisms. Freshly-harvested vegetables are washed, trimmed and cut, then blanched by steaming or dipping in hot water for a few minutes at temperatures close to $100^{\circ} \mathrm{C}$, filled into cans and covered with a hot cover brine, and finally sterilized. However, between blanching and sterilization, vegetables remain at relatively high temperatures that may allow thermophilic bacteria to grow and eventually sporulate. Moreover, spore adhesion to industrial materials and spore resistance to cleaning and disinfection favor spore persistence along the chain (Parkar et al., 2001). A delay in spore release from debris and surfaces may occur, and cross-contamination may emerge long after initial contamination (André et al., 2012; Sànchez et al., 2009; Seale et al., 2008; Tauveron et al., 2006). To better understand contamination pathways and to explore the eventuality of spore formation in the processing chain is therefore necessary for better control of canned food quality.

There are a number of classical and molecular methods for detecting and quantifying spore-forming bacteria from processing lines (Postollec et al., 2012; Prevost et al., 2010). For instance, Bacillus cereus strains isolated at different steps in a processing line of zucchini purée were typed by M13 sequence-based PCR (M13-PCR), an amplification method derived from for Random Amplified Polymorphic DNA (RAPD; Guinebretiere et al., 2003; Guinebretiere and Nguyen-The, 2003). The method clustered strains according to genetic fingerprint and was able to identify contamination pathways: cultivation soil of zucchini and ingredients such as milk proteins and starch were proven to be a major source of primary contamination in zucchini purée. However, the B. cereus genotypes detected in ingredients were not considered a concern in processed products properly stored at cold temperatures. The three genotyping methods RAPD, rpoB sequencing, and multiple loci variable number of tandem repeats analysis (MLVA) applied to $B$. licheniformis thermophilic isolates from milk powder processing line samples and commercial retail samples established that this bacterium derives from non-factory sources and is not subjected to significant clonal selection within processing plants (Dhakal et al., 2013). Highresolution melt analysis of MLV recently applied to Geobacillus species isolated from milk found that several genotypes can coexist in a single processing run, on top of the presence of the same genotypes in samples taken at a 17-year interval (Seale et al., 2012).

The aim of this work was to determine changes in population levels of thermophilic spore-forming bacteria at different steps of the processing chain for canned green peas and carrots. The thermophilic species most frequently involved in spoilage were specifically screened from the processing line. M13-PCR typing was then applied on G. stearothermophilus isolates to clear up the contamination pathways involved. The method was previously described for genetic group differentiation in this species (Durand et al., 2014).

\section{Material and methods}

\subsection{Sampling}

A total of 341 samples ( 263 in 2011 and 78 in 2012) taken for microbiological analyses were collected near or in a single Western-France processing plant during June and July in 2011 and in 2012, over 5 weeks corresponding to the pea harvest period. Samples were obtained from 8 and 13 different days in 2011 and 2012 respectively. The nine soil samples (SL) were collected during the production period of green pea crops intended for processing, and the remaining 332 samples were collected in a French cannery producing canned green peas and a canned mix of green peas and carrots. These samples corresponded to vegetables at different steps of processing (Fig. 1), process liquids, and surface samples from processing equipment. Raw unprocessed green peas were washed by successive immersions in water, then blanched in hot water $\left(95^{\circ} \mathrm{C}\right)$ and convey to the can filler. Carrots were washed with water, peeled, then added to cans previously partfilled with green peas. At this stage, cover brine (ca. $2 \%$ salt wt/vol and $2 \%$ sugar wt/vol in water) was poured into the filled cans. The cans were sealed and heat-sterilized by for an equivalent $121^{\circ} \mathrm{C}$ heating time $\left(\mathrm{F}_{0}\right)$ of over $20 \mathrm{~min}$ before further storage at ambient temperature. Solid and liquid samples were collected with sterile instruments and directly poured into sterile plastic vials. Surfaces of approximately $100 \mathrm{~cm}^{2}$ were wiped with sterile dry sponges moistened with $10 \mathrm{~mL}$ pharmacopeia-grade sodium thiosulfate thinner (VWR BDH Prolabo, Fontenay-sous-Bois, France). Sample numbers and the corresponding sampling stages are reported in Table 1 . Raw green peas (R-P) and raw carrots (R-C) were sampled at the reception deck. Prepared green peas (P-P) were collected immediately before blanching. Blanching water (W) was sampled directly from the blancher. Blanched green peas were sampled immediately after blanching in the processing flow (W-P) as well as lateral debris just after blanching (W-P-OF). Lateral debris during transfer on the conveyor (T-P-OF) was also sampled. Peeled carrots (P-C) were sampled immediately before filling. Both green peas and carrots were collected at the filling machine (T-P/C), again after cover brine was added (B), and again immediately before jarring, aluminum-lidding and sterilization (B-P/C). The cover brine (B) was separately sampled from the pipe recycling excess brine back to the brine tank. In the 2011 campaign, the temperature of each sample was recorded with a digital thermometer (EcoScan Temp5, Fisher, Illkirch, France) immediately after sampling. Mean temperatures are listed in Table 1. In 2011, samples were collected three times a day, i.e. at the beginning (approx. 9-10 am), in the middle (between $2 \mathrm{pm}$ and $3 \mathrm{pm}$ ) and $1 \mathrm{~h}$ before the end of processing (approx. $9 \mathrm{pm}$ ). In 2012, samples were collected once a day, in the middle of processing. Surface samples were collected on the wall of the blancher (W-S), on the conveyor belts used for transfer (T-S), and on the wall of the tank of cover brine (B-S). The surface samples were collected after the day's production run and immediately before the processing line was cleaned. During the 1-month production period, 9 SL samples were collected from the green pea crops. All samples were immediately chilled at $4{ }^{\circ} \mathrm{C}$ post-collection and reached the laboratory within two days, where they were then frozen and stored at $-20^{\circ} \mathrm{C}$ until analysis.

\subsection{Sample preparation for microbiological analysis}

Samples were thawed at $4{ }^{\circ} \mathrm{C}$ one day before the assay. A quantity of $10 \mathrm{~g}$ of solid samples was mixed with $90 \mathrm{~mL}$ Rosenow broth modified by supplementation with $1 \mathrm{~g} / \mathrm{L}$ starch (mRB) (BioRad, Marnes-la-Coquette, France) in a sterile BagFilter ${ }^{\mathrm{TM}}$ (Interscience, Saint-Nom-la-Bretèche, France), and the diluted samples were homogenized for $30 \mathrm{~s}$ using a BagMixer ${ }^{\mathrm{TM}}$ (Interscience). The BagFilter ${ }^{\mathrm{TM}}$ filtrate was used for further enumeration and detection of target microorganisms. Liquid samples were analyzed without any special preparation. Sponges used for surface sampling were placed in sterile bags and covered with $90 \mathrm{~mL}$ $\mathrm{mRB}$, then homogenized for $30 \mathrm{~s}$. The filtrate was recovered after manually wringing the sponge.

\subsection{Anaerobic spore counts}

An aliquot fraction of sample filtrate was placed in a $2.2 \mathrm{~mL}$ sealed glass ampoule and heat-treated for $10 \mathrm{~min}$ at $106{ }^{\circ} \mathrm{C}$ in a temperatureregulated oil bath to select highly-heat-resistant (HHR) thermophilic spores. Another fraction was poured into an $1.7 \mathrm{~mL}$ Eppendorf tube and heat-treated for $10 \mathrm{~min}$ at $100{ }^{\circ} \mathrm{C}$ (André et al, 2013) in a Stuart $\circledast$ SBH130DC Digital Block Heater (Bibby Scientific, Staffordshire, United Kingdom) to select spores of thermophilic bacteria.

Serial dilutions of heat-treated samples in tryptone salt broth were plated $(1 \mathrm{~mL}$ ) on meat liver glucose agar (Biokar Diagnostic, Beauvais, France) modified by supplementation with $2 \mathrm{~g} / \mathrm{L}$ yeast extract (mMLGA) (Sevenier et al, 2012). Plates were incubated at $55^{\circ} \mathrm{C}$ for 5 days in anaerobic jars using Genbox anaer generators (Biomerieux, Craponne, France). Spore counts were calculated with a detection threshold of 10 thermophilic anaerobic spores (TAS)/g and $10 \mathrm{HHR}$ TAS/g for solid samples, $1 \mathrm{TAS} / \mathrm{mL}$ and $1 \mathrm{HHR}$ TAS/mL for liquid samples, 
Vegetable harvest

$\downarrow$

Transportation from

crop to cannery

$\downarrow$

Reception

$\downarrow$

Storage

$\downarrow$

Vegetable preparation

washing, destoning, size sorting

Transfer by conveyor

$\downarrow$

Blanching (peas) I

Peeling (carrots)

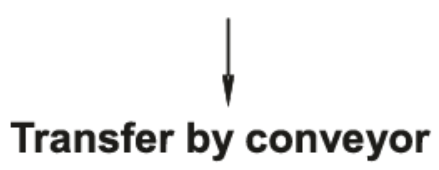

Crop soil (SL)

Raw green peas / carrots

(R-P/R-C)

\author{
Prepared green peas $(P-P)$ \\ Blanching water (W) \\ Blanched green pea / debris \\ (W-P / W-POF) \\ Blancher surface (W-S) \\ Green pea debris (T-POF) \\ Conveyor surface (T-S) \\ Pealed carrots (P-C) \\ Green peas alone or mixed \\ with carrots in-jar (T-P/C) \\ Brine (B) \\ Brine tank surface (B-S)
}

Green peas, alone or mixed with carrots and brine in-jar (B-P/C)

\section{Heat treatment}

Fig. 1. Flow diagram charting green peas and carrots processing steps in the surveyed vegetable cannery.

and $1 \mathrm{TAS} / \mathrm{cm}^{2}$ and $1 \mathrm{HHR}$ TAS $/ \mathrm{cm}^{2}$ for surface samples. This enumeration method counts both strict and facultative thermophilic anaerobes, including G. stearothermophilus and some Bacillus spp.

\subsection{Prevalence of G. stearothermophilus, $M$. thermoacetica/ thermoautotrophica and Thermoanaerobacterium spp.}

Samples diluted in mRB were submitted to a $100{ }^{\circ} \mathrm{C}$ heat selection during 30 min then further incubated for 4 days at $55^{\circ} \mathrm{C}$ for enrichment. The germination and outgrowth of G. stearothermophilus spores after heat-activation were shown to be slightly inhibited or not affected by anaerobiosis (Feeherry et al, 1987; Periago et al,
1998). A $1 \mathrm{~mL}$ volume of the sample was then used to extract total DNA with the InstaGene ${ }^{\mathrm{TM}}$ matrix following the manufacturer's instructions (Bio-Rad, Marnes-la-Coquette, France). G. stearothermophilus, $M$. thermoacetica/thermoautotrophica or Thermoanaerobacterium spp. were specifically detected using the specific PCR technique SporeTraQ ${ }^{\mathrm{TM}}$, as previously developed (Sevenier et al., 2012). Discrimination of the species $M$. thermoacetica from $M$. thermoautotrophica is challenging and $M$. thermoautotrophica could be considered as a sub-species of $M$. thermoacetica (Collins et al., 1994). Briefly, this method amplifies a DNA region corresponding to rRNA internal transcribed sequence 16S$23 \mathrm{~S}$ for $\mathrm{G}$. stearothermophilus and amplifies $16 \mathrm{~S}$ rRNA coding regions for the other bacteria detected. Amplification product sizes were 
Table 1

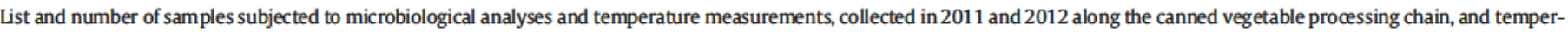
atures recorded in 2011.

\begin{tabular}{|c|c|c|c|c|}
\hline Sample & $\begin{array}{l}\text { Sample } \\
\text { code }\end{array}$ & $\begin{array}{l}\text { Number of samples } \\
\text { collected in } 2011\end{array}$ & $\begin{array}{l}\text { Number of samples } \\
\text { collected in } 2012\end{array}$ & $\begin{array}{l}2011 \text { temperature } \\
(\text { mean } \pm S D)^{b}\end{array}$ \\
\hline Soil of the green peas crop & SL & 8 & $-{ }^{\mathrm{a}}$ & $25.4 \pm 2.5$ \\
\hline Raw carrots (reception deck) & $\mathrm{R}-\mathrm{C}$ & 16 & - & $22.6 \pm 0.4$ \\
\hline Peeled carrots & P-C & 12 & - & nd \\
\hline Raw green peas (reception deck) & R-P & 22 & - & $25.2 \pm 1.7$ \\
\hline Prepared green peas & P-P & 22 & 13 & $17.9 \pm 1.1$ \\
\hline Blanching water & W & 23 & 13 & $85.7 \pm 1.1$ \\
\hline Blanched green peas & W-P & 22 & 13 & $83.9 \pm 4.7$ \\
\hline Blanched green peas, lateral debris & W-POF & 22 & - & $46.6 \pm 5.3$ \\
\hline Blancher surface & W-S & 8 & - & nd \\
\hline Green pea debris on conveyor & T-POF & 23 & 13 & $41.8 \pm 9.2$ \\
\hline Conveyor belt surface & T-S & 8 & - & nd \\
\hline Green peas, alone or mixed with carrots, conveyed to the can filling machine & $\mathrm{T}-\mathrm{P} / \mathrm{C}$ & 23 & - & $43.1 \pm 6.6$ \\
\hline Brine & B & 23 & 13 & $69.3 \pm 7.3$ \\
\hline Brine tank surface & B-S & 8 & - & nd \\
\hline Green peas, alone or mixed with carrots, in cans with cover brine & $\mathrm{B}-\mathrm{P} / \mathrm{C}$ & 23 & 13 & $50.2 \pm 4.3$ \\
\hline
\end{tabular}

nd: not determined.

a No sample analyzed.

b Mean \pm standard deviation. Temperature was measured in the center of the sample immediately after collection.

302 bp, 467 bp and 487 bp corresponding to G. stearothermophilus, $M$. thermoacetica/thermoautotrophica and Thermoanaerobacterium spp., respectively. All amplification steps were performed in a total volume of $25 \mu \mathrm{L}$ with a GeneAmp ${ }^{\circledR}$ PCR System 9700 (Applied Biosystems, USA). PCR products were directly analyzed by electrophoresis in TrisAcetate-EDTA (TAE) buffer 1\% agarose gel. The electrophoretic migration was performed during $30 \mathrm{~min}$ at $150 \mathrm{mV}$. This extraction/amplification method enables a detection threshold of 10 cells per mLenrichment broth (Prevost et al., 2010). Threshold of detection was estimated at one spore per g sample enriched (Sevenier et al., 2012).

\subsection{G. stearothermophilus M13-PCR typing}

Isolation of $G$. stearothermophilus strains was performed from samples tested positive with SporeTraQ ${ }^{\mathrm{TM}}$. A droplet $(10 \mu \mathrm{L})$ of the positive sample was deposited on the bromocresol purple (BCP) surface and incubated for $24 \mathrm{~h}$ at $55^{\circ} \mathrm{C}$, then 3-5 colonies were isolated on BCP and incubated for $24 \mathrm{~h}$ at $55^{\circ} \mathrm{C}$. One loopful of bacterial colony was used to extract total DNA with the InstaGene ${ }^{\mathrm{TM}}$ (Bio-Rad) matrix following the manufacturer's instructions. G. stearothermophilus was specifically detected by SporeTraQ ${ }^{\mathrm{TM}}$ PCR as described above. Then, DNA of positively-testing bacterial isolates was extracted with chloroform/ phenol and amplified with PM13 primer as described previously, with modifications (Durand et al., 2014; Guinebretiere and Nguyen-The, 2003). A negative control containing Milli- $Q$ water instead of DNA and a positive control with the DNA of B. cereus strain ATCC 14579 producing a regular banding pattern were included in each PCR experiment. A G. stearothermophilus isolate recovered from spoiled canned green peas in 2010 was included in the panel and labeled \#124 (Durand et al., 2014).

PCR products from M13-PCR were separated by electrophoresis on $1.5 \%$ agarose gels in $0.5 \times$ TBE buffer ( $20 \mathrm{mM}$ Tris, $10 \mathrm{mM}$ acetic acid, 0.5 mM EDTA, pH 8) using Eurogentec Smart Ladder. The electrophoretic migration was performed successively with one step at $120 \mathrm{mV}$ during $15 \mathrm{~min}$ and then a second step at $80 \mathrm{mV}$ during $3 \mathrm{~h}$. Gels were stained with ethidium bromide and digitized using a UV gel imager (Molecular Imager® Gel Doc ${ }^{\mathrm{TM}}$ XR System 170-8170, BioRad, Marnesla-Coquette, France). A dendrogram was constructed from the similarity of M13-PCR banding patterns (Dice's coefficient) and using the unweighted pair group method with arithmetic mean (UPGMA). Band detection, similarity coefficient and dendrogram were realized using BioGene 99.04 software (Vilber Lourmat, Marne-la-Vallée, France). The confidence interval on band size was adjusted to obtain $100 \%$ similarity between independent replicates of control strains.

\subsection{Statistical analyses}

All statistical analyses were carried out with XLSTAT software (Addinsoft ${ }^{\mathrm{TM}}$, Paris, France). Statistical analyses were performed on $\log _{10}$ transformed counts. Numeration data below the threshold of detection were set to threshold divided by square root of two (Hornung and Reed, 1990). Data were analyzed by one-way ANOVA. P-value was set at 0.05 . The Bonferroni test was applied to detect significant differences between means. The confidence interval of proportions at $95 \%$ was determined as the value corresponding to $1.96 \times$ standard deviation (SD). Proportion comparisons were performed according to Fleiss et al. (2004).

\section{Results}

3.1. Enumeration of thermophilic anaerobic spores (TAS) and highly-heatresistant (HHR) TAS

TAS and HHR TAS were enumerated in all samples collected in 2011 and 2012 (Table 2 and Fig. 2). The highest TAS count means found in 2011 were in soil (SL) and raw carrots (R-C), at $3.2 \pm 0.5 \log _{10} \mathrm{cfu} / \mathrm{g}$ and $3.1 \pm 1.0 \log _{10} \mathrm{cfu} / \mathrm{g}$, respectively. Globally, HHR TAS counts were lower than TAS counts, but the highest HHR TAS were also found in SL and R-C samples, at $2.7 \pm 0.2 \log _{10} \mathrm{cfu} / \mathrm{g}$ and $2.3 \pm 0.8 \log _{10} \mathrm{cfu} / \mathrm{g}$, respectively. These population levels significantly differed from other counts. Raw pea (R-P) TAS and HHR TAS populations (2.0 \pm $0.4 \log _{10} \mathrm{cfu} / \mathrm{g}$ and $1.2 \pm 0.5 \log _{10} \mathrm{cfu} / \mathrm{g}$, respectively) were significantly lower $(\mathrm{P}<0.05)$ than the population counts found in soil samples and raw carrots.

Spore counts of vegetables decreased during the vegetable preparation process chain at ambient temperature until pea blanching (W-P samples) and carrot peeling ( $\mathrm{P}-\mathrm{C}$ samples), then remained unchanged through to final processing in $\mathrm{T}-\mathrm{P} / \mathrm{C}$ and $\mathrm{B}-\mathrm{P} / \mathrm{C}$ samples. TAS and HHR TAS counts from washed-and-peeled carrots (P-C) were $0.4 \pm$ $0.0 \log _{10} \mathrm{cfu} / \mathrm{g}$ and $0.5 \pm 0.0 \log _{10} \mathrm{cfu} / \mathrm{g}$, respectively. TAS and HHR TAS counts from prepared peas (P-P) were $1.3 \pm 0.6 \log _{10} \mathrm{cfu} / \mathrm{g}$ and $0.6 \pm 0.1 \log _{10} \mathrm{cfu} / \mathrm{g}$ respectively, with HHR TAS counts significantly lower $(\mathrm{P}<0.05)$ than raw pea $(\mathrm{R}-\mathrm{P})$ counts. From the pea blanching step (W-P) to in-can brining (B-P/C), there was no detectable variation in mean population. Furthermore, mean TAS counts were lowest in blanched peas (W-P), peas alone or mixed with carrots and filled incan (T-P/C), blanching water (W), and brine (B), and ranged from $0.3 \pm 0.7 \log _{10} \mathrm{cfu} / \mathrm{g}$ or $/ \mathrm{mL}$ to $0.6 \pm 0.4 \log _{10} \mathrm{cfu} / \mathrm{g}$ or $/ \mathrm{mL}$. HHR TAS 
Table 2

Thermophilic anaerobic spore (TAS) and highly-heat-resistant (HHR) TAS counts from vegetable samples collected in 2011 and 2012 from the canned vegetable processing chain.

\begin{tabular}{|c|c|c|}
\hline \multirow[t]{2}{*}{ Samples $^{\mathrm{a}}$} & \multicolumn{2}{|c|}{$\begin{array}{l}\text { Microbiological counts }\left(\log _{1} \mathrm{cfu} / \mathrm{g} \text { or } \mathrm{mL} \text { or } \mathrm{cm}^{2}\right)^{\mathrm{b}} \\
(\text { mean } \pm \mathrm{SD}) \text { in year }\end{array}$} \\
\hline & 2011 & 2012 \\
\hline \multicolumn{3}{|c|}{ Thermophilic anaerobic spores } \\
\hline SL & $3.2 \pm 0.5 \mathrm{~A}$ & $-^{c}$ \\
\hline $\mathrm{R}-\mathrm{C}$ & $3.1 \pm 1.0 \mathrm{~A}$ & - \\
\hline $\mathrm{P}-\mathrm{C}$ & $0.4 \pm 0.0 \mathrm{E}$ & - \\
\hline R-P & $2.0 \pm 0.4 \mathrm{BC}$ & - \\
\hline P-P & $1.3 \pm 0.6 \mathrm{CD}$ & $0.6^{\mathrm{d}} \pm 0.3 \mathrm{~A}$ \\
\hline W & $0.6 \pm 0.5 \mathrm{E}$ & $0.7 \pm 0.6 \mathrm{~A}$ \\
\hline W-P & $0.5 \pm 0.3 \mathrm{E}$ & $0.5 \pm 0.2 \mathrm{~A}$ \\
\hline W-POF & $2.4 \pm 0.9 \mathrm{AB}$ & - \\
\hline W-S & $0.9 \pm 0.7 \mathrm{DE}$ & - \\
\hline T-POF & $1.2 \pm 0.4 \mathrm{D}$ & $0.5^{\mathrm{d}} \pm 0.2 \mathrm{~A}$ \\
\hline T-S & $0.0 \pm 0.4 \mathrm{~F}$ & - \\
\hline $\mathrm{T}-\mathrm{P} / \mathrm{C}$ & $0.5 \pm 0.4 \mathrm{E}$ & - \\
\hline B & $0.3 \pm 0.7 \mathrm{E}$ & $0.2 \pm 0.5 \mathrm{~A}$ \\
\hline B-S & $1.1 \pm 1.2 \mathrm{DE}$ & - \\
\hline $\mathrm{B}-\mathrm{P} / \mathrm{C}$ & $1.0 \pm 0.8 \mathrm{DE}$ & $1.8 \pm 1.0 \mathrm{~B}$ \\
\hline \multicolumn{3}{|c|}{ Highly-heat-resistant thermophilic anaerobic spores } \\
\hline SL & $2.7 \pm 0.2 \mathrm{~A}$ & - \\
\hline $\mathrm{R}-\mathrm{C}$ & $2.3 \pm 0.8 \mathrm{AB}$ & - \\
\hline $\mathrm{P}-\mathrm{C}$ & $0.6 \pm 0.0 \mathrm{EF}$ & - \\
\hline R-P & $1.2 \pm 0.5 \mathrm{D}$ & - \\
\hline P-P & $0.6 \pm 0.1 \mathrm{EF}$ & $0.6^{\mathrm{d}} \pm 0.1 \mathrm{~A}$ \\
\hline W & $0.4 \pm 0.5 \mathrm{~F}$ & $0.8 \pm 0.7 \mathrm{~A}$ \\
\hline W-P & $0.6 \pm 0.0 \mathrm{EF}$ & $0.8 \pm 0.3 \mathrm{~A}$ \\
\hline W-POF & $2.0 \pm 0.9 \mathrm{BC}$ & - \\
\hline W-S & $0.0 \pm 0.5 \mathrm{~F}$ & - \\
\hline T-POF & $0.9 \pm 0.2 \mathrm{DE}$ & $0.7^{\mathrm{d}} \pm 0.3 \mathrm{~A}$ \\
\hline T-S & $-0.1 \pm 0.0 \mathrm{G}$ & - \\
\hline $\mathrm{T}-\mathrm{P} / \mathrm{C}$ & $0.6 \pm 0.1 \mathrm{EF}$ & - \\
\hline B & $0.3 \pm 0.5 \mathrm{~F}$ & $0.8 \pm 1.2 \mathrm{~A}$ \\
\hline B-S & $1.4 \pm 0.9 \mathrm{CD}$ & - \\
\hline B-P/C & $0.6 \pm 0.1 \mathrm{EF}$ & $1.1 \pm 0.6 \mathrm{~A}$ \\
\hline \multicolumn{3}{|c|}{$\begin{array}{l}\text { a The different samples were SL, Soil; R-C, Raw carrot; P-C, Peeled carrot; R-P, Raw green } \\
\text { peas; P-P, Prepared green peas; W, Blanching water; W-P, Blanched green peas; W-POF, } \\
\text { Blanched green peas, lateral debris; W-S, Blancher surface; T-POF, Green pea debris on } \\
\text { conveyor; T-S, Conveyor belt surface; T-P/C, Green peas, alone or mixed with carrots, } \\
\text { transferred to the can filling machine; B, Brine; B-S, Brine tank surface; B-P/C, Green peas, } \\
\text { alone or mixed with carrots, in cans with cover brine. } \\
\text { b Values are expressed as } \log _{10} \mathrm{cfu} / \mathrm{g} \text { for solid samples, } \log _{10} \mathrm{cfu} / \mathrm{mL} \text { for liquid samples } \\
\text { and } \log _{10} \mathrm{cfu} / \mathrm{cm}^{2} \text { for surface samples. Different letters between samples of the same year } \\
\text { correspond to significant differences (P<0.05). } \\
\text { c No sample analyzed. } \\
\text { d Significant difference between samples collected in } 2011 \text { and } 2012 \text { at } \mathrm{P}<0.05 \text {. }\end{array}$} \\
\hline
\end{tabular}

counts were also lowest in W-P, T-P/C, W and B samples, and were in the same range as mean TAS counts. For the whole transformation process, a ca. 10-fold decrease of spore contamination was observed both for TAS and for HHR TAS, as populations of sporeforming bacteria in canned peas (B-P/C) were 0.6 to $1.0 \mathrm{log} \mathrm{cfu} / \mathrm{g}$ lower than the population in the raw material (R-P). Interestingly, beside the variations of count means, extreme values of counts increased considerably from blancher step (W and W-P) to brine filling step (T-P/C and B-P/C) (Fig. 2). Amplitude of $\log _{10}$ spore counts in blanching water (W), cover brine (B), and canned product before heat treatment (B-P/C) varied from 0.65 to $2.45 \log _{10} \mathrm{cfu} / \mathrm{g}$ or $/ \mathrm{mL}$.

The TAS and HHR TAS populations determined in debris (W-POF and T-POF) ranged from $1.2 \pm 0.4 \log _{10}$ cfu/g to $2.4 \pm 0.9 \log _{10} \mathrm{cfu} / \mathrm{g}$ for TAS and from $0.9 \pm 0.2 \log _{10} \mathrm{cfu} / \mathrm{g}$ to $2.0 \pm 0.9 \log _{10} \mathrm{cfu} / \mathrm{g}$ for HHR TAS. The number of TAS collected on equipment surfaces (W-S, T-S and B-S) at the close of the production day ranged from $0.0 \log _{10} \mathrm{cfu} / \mathrm{cm}^{2}$ to $1.1 \pm 1.2 \log _{10} \mathrm{cfu} / \mathrm{cm}^{2}$, and the number of HHR TAS ranged from $0.0 \log _{10} \mathrm{cfu} / \mathrm{cm}^{2}$ to $1.4 \pm 0.9 \log _{10} \mathrm{cfu} / \mathrm{cm}^{2}$. $\log _{10}$ spore counts varied strongly according to surface sample, and the amplitudes were up to $1.15 \log _{10} \mathrm{cfu} / \mathrm{cm}^{2}$.

\subsection{Temperature measurement along the processing chain}

Temperatures measured in 2011 throughout the processing chain (Table 1) ranged from $17.9-25.4{ }^{\circ} \mathrm{C}$ (ambient temperature) to $85.7 \pm$ $1.1{ }^{\circ} \mathrm{C}$ (blanching water). Pea temperature remained high postblanching, at $83.9 \pm 4.7^{\circ} \mathrm{C}$. Temperatures of T-P/C, B-P/C and B samples were $43.1 \pm 6.6{ }^{\circ} \mathrm{C}, 50.2 \pm 4.3^{\circ} \mathrm{C}$ and $69.3 \pm 7.3^{\circ} \mathrm{C}$, respectively. Temperatures of W-POF and T-POF lateral debris were $46.6 \pm 5.3^{\circ} \mathrm{C}$ and $41.8 \pm 9.2^{\circ} \mathrm{C}$, respectively. Note that standard deviation on all sample temperatures increased sharply after the blanching step.

\subsection{Prevalence of $M$. thermoacetica/thermoautotrophica, Thermoanaerobacterium spp. and G. stearothermophilus}

A total of 333 samples collected in 2011 and 2012 and anaerobically enriched for analysis were screened to test for the thermophilic species $M$. thermoacetica/thermoautotrophica, Thermoanaerobacterium spp. and G. stearothermophilus (Fig. 3). Depending on nature of the sample, the prevalence of $G$. stearothermophilus ranged from $0 \%$ to $100 \%$ and the prevalence of $M$. thermoacetica/thermoautotrophica ranged from $0 \%$ to 91\%. In contrast, Thermoanaerobacterium spp. was never detected in samples except in $17 \%$ of blanching water from year-2011 samples, and was therefore considered a minor microbiological contaminant in the processing plant at the time of survey (data not shown). The prevalence of $G$. stearothermophilus was (prevalence \% [0.95 confidence interval \%]) $5 \%[1 ; 22]$ in raw peas (R-P) and $13 \%[3 ; 36]$ in raw carrots $(\mathrm{R}-\mathrm{C})$. The prevalence of $M$. thermoacetica/thermoautotrophica was $9 \%[3 ; 28]$ in raw peas and $0 \%[0 ; 19]$ in raw carrots. Both these bacteria progressively increased in prevalence in green pea samples along the process. G. stearothermophilus was detected in $18 \%$ [7; 39], 59\% [39; 77] and $65 \%[45 ; 81]$ of P-P, W-P and T-P/C samples, respectively. $M$. thermoacetica/thermoautotrophica was detected in $23 \%[10 ; 43], 82 \%$ $[61 ; 93]$ and $61 \%[41 ; 78]$ of P-P, W-P and T-P/C samples, respectively. A peak in $M$. thermoacetica/thermoautotrophica prevalence, i.e. $91 \%$ [73; 98], was found in the in-can brine-covered product, with or without carrots (B-P/C). Cover brine (B) showed low prevalence values of $G$. stearothermophilus and $M$. thermoacetica/thermoautotrophica. Interestingly, a peak in G. stearothermophilus prevalence was in blanching water $(\mathrm{W})$, where it reached $100 \%[86 ; 100]$. G. stearothermophilus prevalence was significantly different between raw and blanched peas and between prepared peas and blanching water (Suppl. Table 1). M. thermoacetica/thermoautotrophica prevalence was significantly different between R-P and B-P, between P-P and B-P, and between R-P or $\mathrm{R}-\mathrm{C}$ and T-P/C samples.

Surfaces from the blancher (W-S) and transfer conveyor (T-S) and samples from out-of-flow peas as lateral debris (W-POF and TPOF) showed high prevalence values of G. stearothermophilus spores at up to $100 \%$. M. thermoacetica/thermoautotrophica prevalence in surface, debris and conveyed samples was in the range $13-50 \%$. The brine tank surface (B-S) showed moderate prevalence values of $25 \%$ [7; 59] for G. stearothermophilus and $13 \%$ [2; 47] for $M$. thermoacetica/thermoautotrophica.

G. stearothermophilus and M. thermoacetica/thermoautotrophica prevalence values did not differ significantly between year-2011 and year-2012 samples, except for $M$. thermoacetica/thermoautotrophica prevalence in B-P/C and G. stearothermophilus prevalence in T-POF.

\subsection{Analysis of the diversity among G. stearothermophilus isolates with M13-PCR}

A total 112 (87 in 2011 and 25 in 2012) G. stearothermophilus strains were isolated and genotyped by M13-PCR. An electrophoresis pattern was obtained for each isolate. Number of 200 to 4000 -bp DNA bands varied from 10 to 17 . A similarity threshold set at $97 \%$ resulted in 9 groups and 14 singletons (Fig. 4 and Suppl. Fig. 1). In parallel, visual observation of M13-PCR patterns allowed to identify only 14 profile-types 

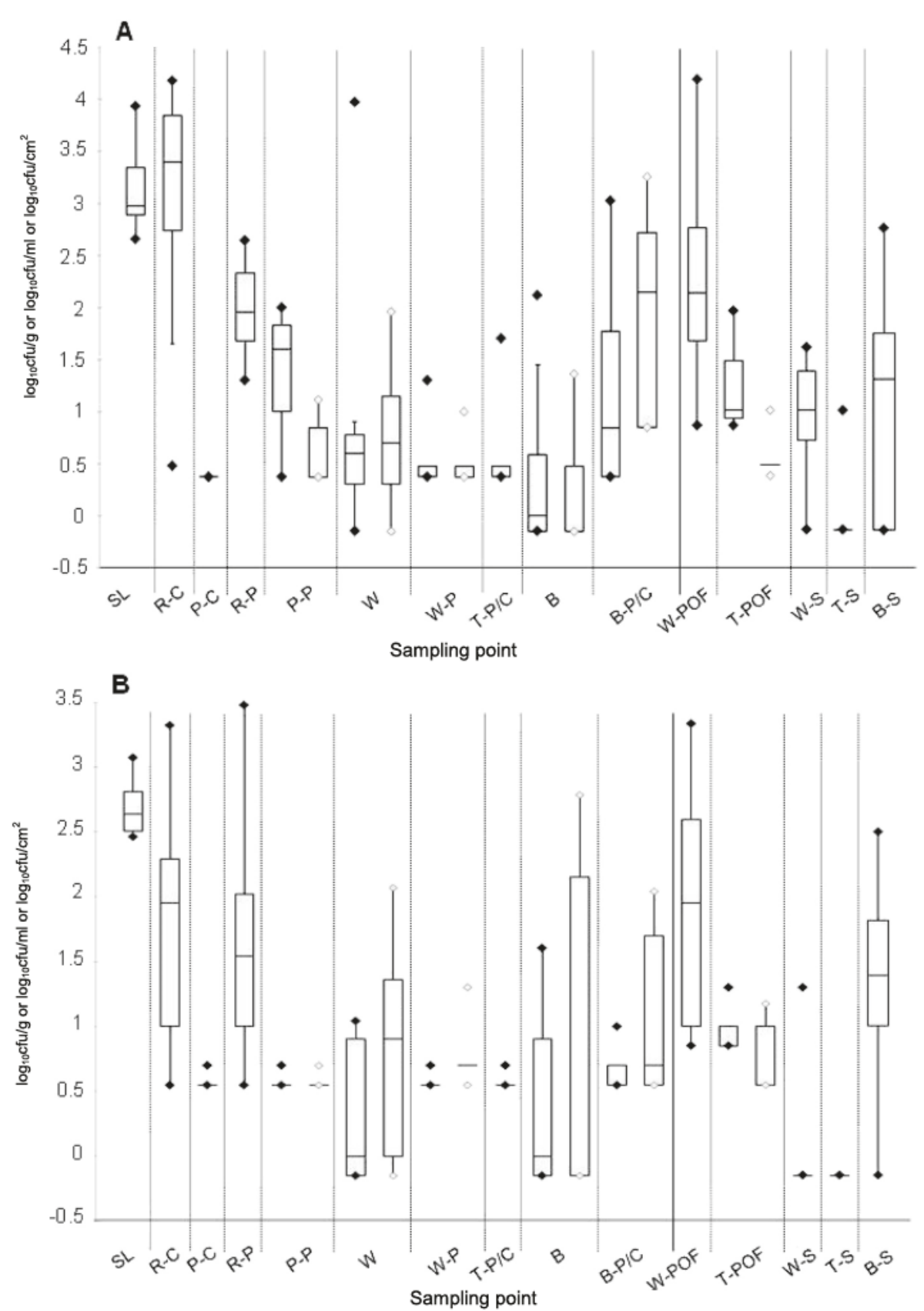

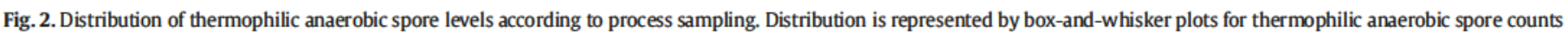

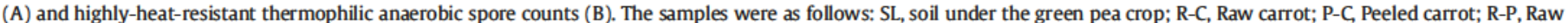

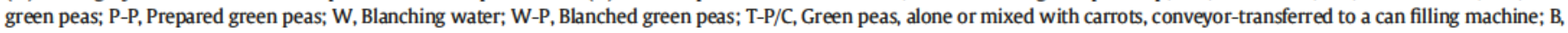

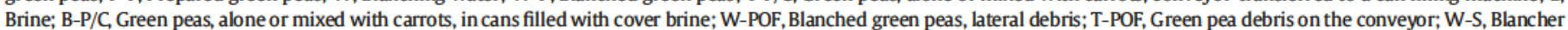

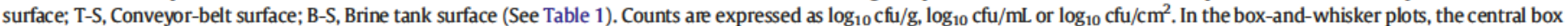

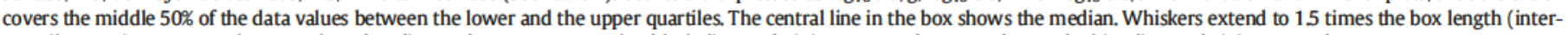
quartile range). Extreme values are plotted as diamonds. For some samples, black diamonds ( $\bullet$ ) correspond to 2011 data and white diamonds ( $\diamond)$ to 2012 data.

classifiable in 8 groups and 6 singletons. A global coherence with the dendrogram groups and singletons was clearly observed but $10 \%$ of strains ( 8 singletons and group No. 5) were not allocated to the true group due to errors generated by the automatic band detection system, in the present experimental conditions (Suppl. Fig. 1). Thus, the erroneous singletons $3,4,15,17,18,19,20,21$ and group No. 5 were reclassified in the true remaining groups (see Suppl. Fig. 1) as presented in Table 3.

Four major groups were recorded at different step on the processing line (Table 3), among those group 6 was the largest (45\% of all isolates). Group 6 was representative of year 2011 only and was not recovered in the final product despite its large dominance in debris and surfaces.
Among the three other major groups (groups 12,1, 10), groups 1 and 10 were also representative of year 2011, whereas group 12 isolates were recovered from both 2011 and 2012. Groups 1, 22 and 7 were also recovered in the final product as well as group 12, and it appeared that these final contaminations originated from blanching water and blanched peas and further from post-blanching samples (transfer debris (T-POF), brine (B)).

Within the profile-types, certain bands were specific to a given group and were characterized by higher fingerprint intensity and/or a specific size (Suppl. Fig. 1). Each electrophoretic pattern from groups $1,12,10$ and 14 exhibited one characteristic marker-band at respectively 420 bp, 730 bp, 470 bp and 2800 bp. Note that, by means of 730 bp 
A1

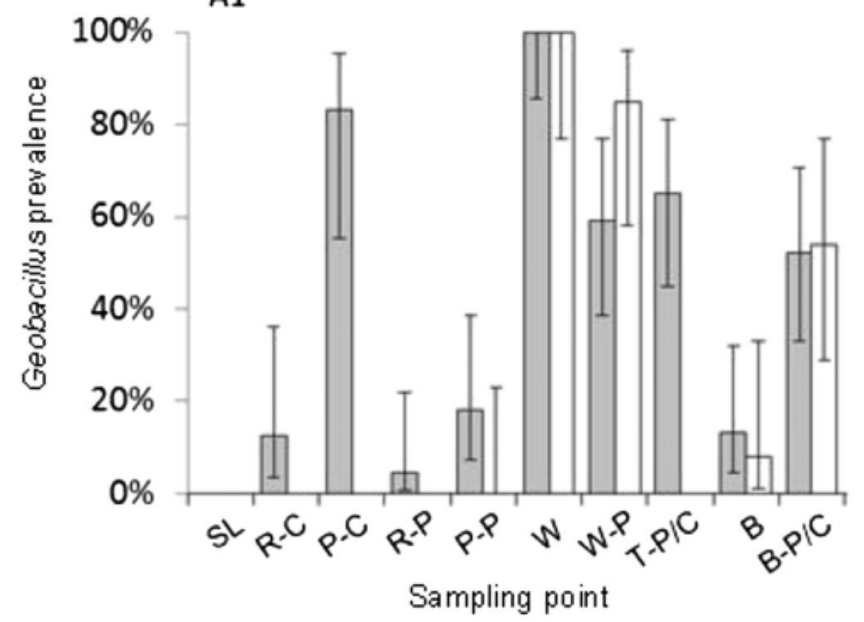

B1

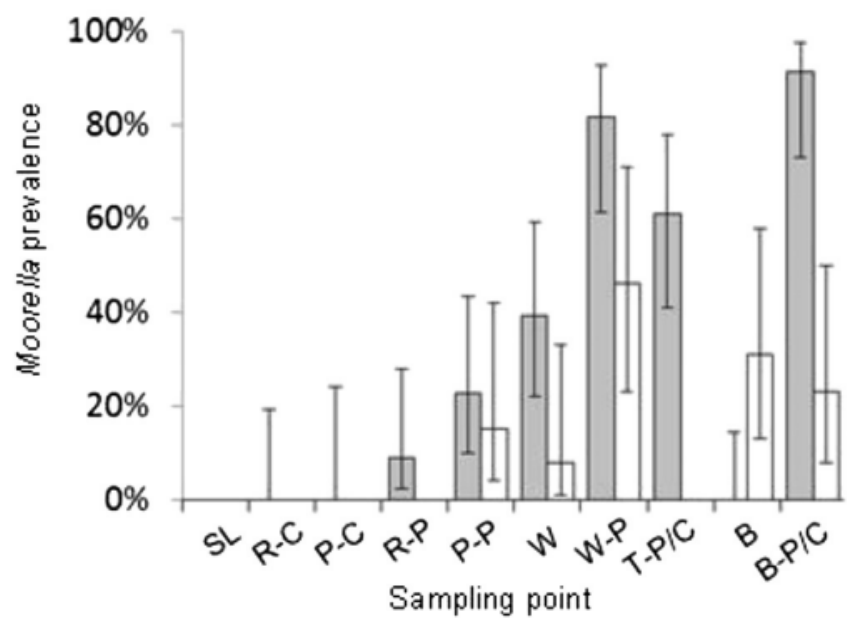

A2

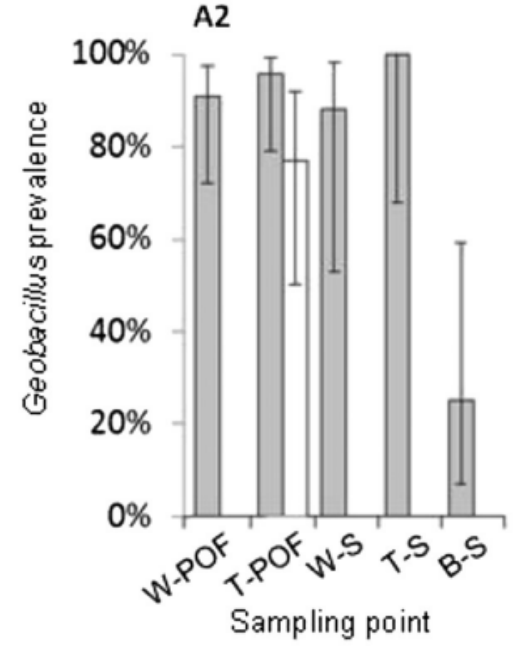

B2

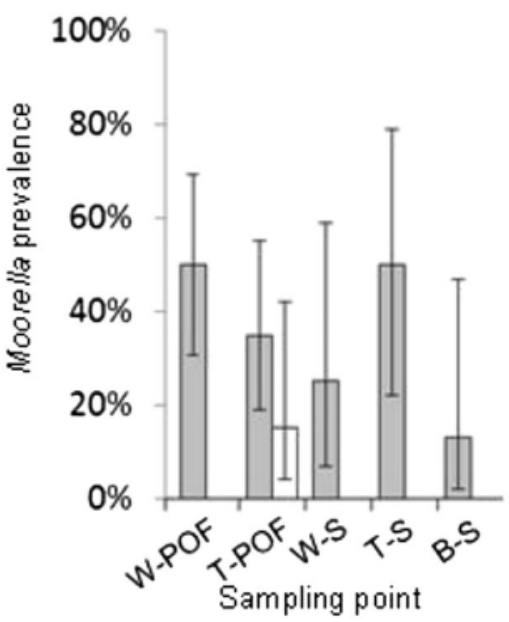

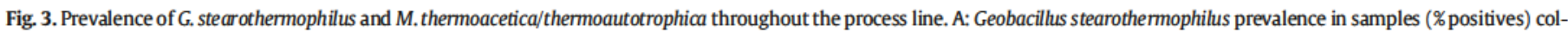

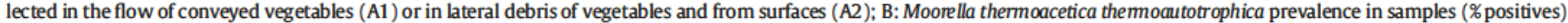

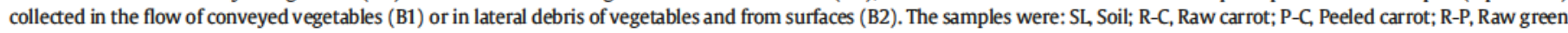

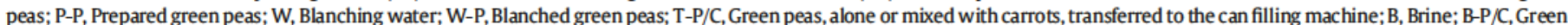

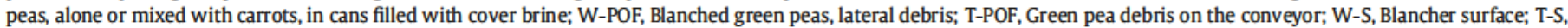

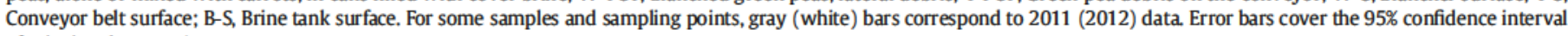
of calculated proportions.

marker-band, the profile-type of group 12 was easily recovered on several G. stearothermophilus strains involved in canned vegetables spoilage (before 2010), one of which (\#124; Durand et al., 2014) was independently isolated in 2010 from spoiled canned green peas produced at the same cannery as surveyed here (Fig. 4).

\section{Discussion}

Microbiological non-stability of canned food due to thermophilic bacteria causes significant economic costs in industrial canning. Thermophilic spores surviving heat treatment is the main cause of spoilage of canned foods. Better knowledge of spore contamination levels and of the prevalence of the main spoilage-induced spore former species throughout the processing-line is vital in order to better rationalize the heat treatment and hygiene procedures. In addition, such species could be of interest as biological indicators for new thermal technological treatments. Here we examined several zones of the production line from raw vegetables to in-can product before heat treatment. The prevalence of the three thermophilic bacteria most frequently implicated in canned food spoilage (André et al., 2013) was determined after sample enrichment using a sensitive method developed previously (Prevost et al., 2010). Thermoanaerobacterium spp. was rarely detected in this study, thus confirming its low prevalence in canned vegetables and spoilage (ca. $5 \%$ of cases in canned vegetables according to André et al. (2013)).

In this study, the average population of thermophilic spores in crop soil was $3 \log _{10} \mathrm{cfu} / \mathrm{g}$. The highest spore population was found in raw carrots, where the average population was close to the figure reported by Sevenier et al. (2012) in the same product $(2.6 \pm$ $0.1 \log _{10} \mathrm{cfu} / \mathrm{g}$ ), but with a much higher dispersion of values in our study. However, raw vegetables showed low prevalence levels (0-24\%) of G. stearothermophilus and M. thermoacetica/thermoautotrophica, as previously observed (Sevenier et al., 2012). Soil can be therefore considered a highly probable source of spore contamination in the industrial plant studied. Direct contact with soil could explain the higher spore populations on carrots than on peas which grow in aerial part of plants. Raw materials were thus a major vector of HHR spores into the processing line. Similar conclusions were reached for pathways of zucchini contamination by B. cereus (Guinebretiere et al., 2003).

The marked decrease in spore counts in the course of processing operations at ambient temperature, especially between reception of the raw vegetables and after preparation for blanching, could be explained 


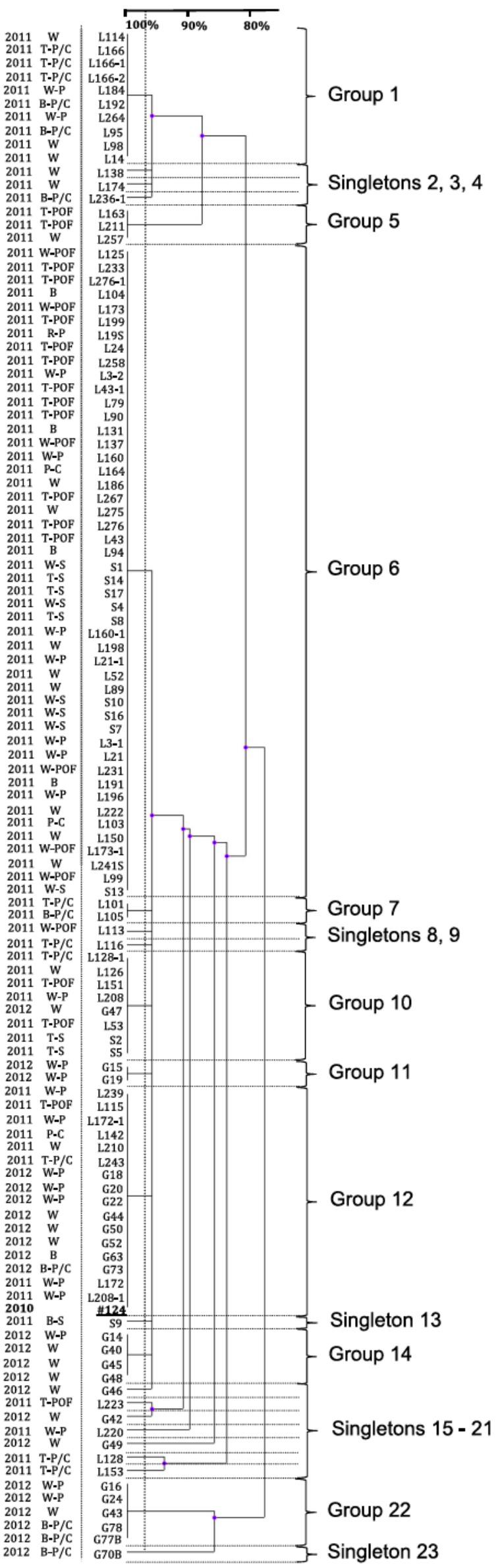

by multiple washing steps, as previously suggested (Sevenier et al., $2012)$. Raw vegetables were prepared at room temperature $\left(8^{\circ} \mathrm{C}\right.$ to $25^{\circ} \mathrm{C}$ ) which likely impairs the multiplication and sporulation of thermophilic bacteria (Scott et al., 2007). After vegetable preparation, spore populations at entry to the high-temperature processing (i.e. $>41{ }^{\circ} \mathrm{C}$ ) zone were low ( 0.4 to $1.3 \mathrm{log} \mathrm{cfu} / \mathrm{g}$ ). At this stage of the process, prevalence levels were 3-39\% for G. stearothermophilus and 0-43\% for $M$. thermoacetica/thermoautotrophica.

The range of temperatures supporting the growth of thermophilic spore-formers, including $G$. stearothermophilus and $M$. thermoacetica (Coorevits et al., 2012; Fontaine et al., 1942; Wiegel, 2009), suggests that the multiplication and ultimate sporulation of thermophiles may only occur in a few niches along the processing line. Here, these niches were probably out-of-flow peas with prolonged residence times, recycled brine, peas in cans, alone or mixed with carrots, with or without brine, and probably also process-line surfaces, as the temperatures were in the range $41^{\circ} \mathrm{C}-69^{\circ} \mathrm{C}$. The residence time of properly conveyed vegetables seems to be short enough to prevent significant growth or sporulation, as vegetable TAS and HHR TAS populations remained unchanged after blanching. In contrast, high residence time (over several hours) of contaminated food material is a common feature on equipment surfaces, in processing liquid samples, and in debris not conveyed in the main vegetable stream. For instance, accumulated vegetable debris on the lateral side of the chain were only eliminated during cleaning at the end of the production day. Nutrients are available in the processed food itself or in recycled brine by diffusion of food constituents, which could enable local growth and eventually sporulation. In addition, all these niches are encountered after blanching and the blanching step may induce germination of spores. Spores accumulated on surfaces and in vegetable debris may be randomly released in the course of production, leading to high variations in product spore counts before thermal treatment. This is confirmed by $G$. stearothermophilus genotypic analysis which showed the presence of isolates from groups 10 and 12 at different accumulation locations and in-can vegetables.

One striking observation was the large increase in prevalence of $G$. stearothermophilus and $M$. thermoacetica/thermoautotrophica at the blanching step. Blanching temperature is not compatible with spore formation or vegetative cell multiplication. This process step is designed to inactivate enzymes and vegetative cells and to fix green pea color. As expected, blanching inactivates many thermophilic anaerobic spores but much less HHR TAS. This is observed from count differences between TAS and HHR TAS which became null in post-blanching samples. The heat treatment applied in the blanching water may select HHR spore-formers such as $G$. stearothermophilus and $M$. thermoacetica/ thermoautotrophica. The blancher in the surveyed processing chain worked with continuous water recycling and steam production during vegetable processing. A very likely hypothesis to explain the prevalence increase is that HHR spores entered the blancher with prepared green peas and were partly released in the vegetable water, where they accumulated and then cross-contaminated peas that later went through the blanching tank.

Interestingly, most of $G$. stearothermophilus genetic groups determined in this study were found in blanching-water isolates. Isolates from blanching water and blanched peas were distributed in the same genetic groups and at similar proportions. Three out of the four groups detected in the final product before heat treatment also include isolates from the blancher step, both in water and blanched peas, and to a lesser extent isolates from transfer debris, brine or transfer surfaces. This clearly shows that the blanching step contributed to the dissemination of strains to the product before heat treatment. Group 6 isolates were

Fig. 4. Dendrogram of G. stearothermophilus isolate profile-types obtained with the M13PCR method. Percent similarity represented by the horizontal scale was calculated using Dice's coefficient, and clustering was performed by UPGMA. Profile-types obtained at a set $97 \%$ similarity threshold are separated with the vertical scale and labeled with their group or singleton numbers. 
Table 3

Distribution of G. stearothermophilus isolates collected in 2011 and 2012 according to sampling origin and M13-PCR groups.

\begin{tabular}{|c|c|c|c|c|c|c|c|c|c|c|}
\hline \multirow[t]{2}{*}{ Sample origin $^{\mathrm{a}}$} & \multirow[t]{2}{*}{ Number of isolates } & \multicolumn{9}{|c|}{ Number of isolates by profile-type ${ }^{b}$} \\
\hline & & 6 & 12 & 1 & 10 & 22 & 14 & 7 & 11 & $\overline{\text { Ungrouped profile-types }}{ }^{c}$ \\
\hline R-P & 1 & 1 & & & & & & & & \\
\hline W & 27 & 8 & $4(3)$ & 4 & $2(1)$ & $1(1)$ & $6(6)$ & & & 1 \\
\hline W-P & 23 & 7 & $8(3)$ & 2 & 1 & $2(2)$ & $1(1)$ & & $2(2)$ & $1(1)$ \\
\hline W-POF & 7 & 6 & & & & & & & & 1 \\
\hline W-S & 6 & 6 & & & & & & & & \\
\hline $\mathrm{P}-\mathrm{C}$ & 2 & 2 & & & & & & & & \\
\hline T-POF & 17 & 11 & 1 & & 2 & & & & & 1 \\
\hline T-S & 5 & 3 & & & 2 & & & & & \\
\hline $\mathrm{T}-\mathrm{P} / \mathrm{C}$ & 10 & & 2 & 3 & 3 & & & 1 & & 1 \\
\hline B & 5 & 4 & $1(1)$ & & & & & & & \\
\hline B-S & 1 & & & & & & & & & 1 \\
\hline $\mathrm{B}-\mathrm{P} / \mathrm{C}$ & 8 & & $1(1)$ & 3 & & $2(2)$ & & 1 & & \\
\hline Total $(2012)^{\mathrm{b}}$ & $112(25)$ & 51 & $17(8)$ & 12 & $10(1)$ & $5(2)$ & $7(7)$ & 2 & $2(2)$ & $6(1)$ \\
\hline
\end{tabular}

a The samples were collected at different stages of the processing line: R-P, Raw green peas; W, Blanching water; W-P, Blanched green peas; W-POF, Blanched green peas, lateral debris;

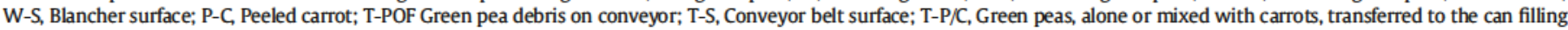
machine; B, Brine; B-S, Brine tank surface and B-P/C, Green peas, alone or mixed with carrots, in cans with cover brine.

b In brackets, number of isolates collected in 2011.

c singletons.

evenly distributed in the processing chain between debris, surface, brine and blancher water, but in higher proportions compared to conveyed blanched peas. The absence of group 6 isolates in the final product supports the assumption that final product contamination mostly reflects in-flow pea and carrot contamination rather than accumulation and release events. However, accumulation and release events may explain individual cases of microbiologically unstable canned food despite monitoring of $\mathrm{F}_{0}$ values. The isolates found in the canned product, with or without brine, belonged to four groups, numbered $1,7,12$ and 22 . In this study, marker-bands were specifically detected for groups 1, 10,12, 14 and 23. Moreover, a G. stearothermophilus isolate from spoiled canned green peas at the same cannery presented one of these marker-bands. Naturally, the clonal status of independent isolates collected during a long time interval has to be confirmed by a second typing method. If the presence of this marker-band is confirmed by further M13-PCR typing of isolates implicated in spoilage cases, and provided that this band exhibits the same sequence in different strains, the sequence of this band could be further used for specific pre-heattreatment detection of canned food spoilage-related isolates.

We examined the persistence of profile-types over a one year interval. Genetic groups 1,6 and 7 were specifically detected in 2011 whereas groups 11,14 and 22 were 2012-specific. Group 12 isolates were found in both 2011 and 2012. Group 10, essentially detected in 2011, also had one representative in the 2012 isolates. This temporal distribution indicates annual variations in the most frequent isolates from vegetables despite geographically identical crop location and processing environment. The presence of the same profile-types in two consecutive years could be explained by persistence of certain bacterial strains either in soil or in the processing plant, but the broad renewal of profile-types observed over two consecutive years suggests that the location effect is minor. Further examination of soil and equipment contamination between several production campaigns is necessary to elucidate this point.

The observed cross-contamination of vegetables during the blanching step together with HHR spore selection, the presence of zones of vegetable accumulation supporting spore level increases, and the occasional release of spores to conveyed vegetables gives evidence that blancher and conveyors are critical points for microbial contamination of food before thermal treatment. In conclusion, processing plant modification should be made a priority in order to reduce the incidence of microbiological non-stability in canned food.

Supplementary data to this article can be found online at http://dx. doi.org/10.1016/j.ijfoodmicro.2015.02.019.

\section{Acknowledgments}

This work is a subpart of author Loïc Durand's $\mathrm{PhD}$ thesis project for which he received a grant from the Association Nationale de la Recherche et de la Technologie, Paris, France. The research work was supported by France AgriMer grants 2012-0523 and 2013-0737 and by the Conseil Regional Provence-Alpes-Côte d'Azur (DIVERSITHER project, grant 2011-24688). This research work is also a contribution to research activities led by the Unité Mixte Technologique Qualiveg.

\section{References}

AFNOR, 1997. Contrôle de la stabilité des produits appertisés et assimilés-Méthode de routine, Microbiologie des aliments, vol. NF V 08-408. Afnor, Paris.

André, S., Hédin, S., Remize, F., Zuber, F., 2012. Evaluation of peracetic acid sanitizers efficiency against spores isolated from spoiled cans in suspension and on stainless steel surfaces. J. Food Prot. 75, 371-375.

André, S., Zuber, F, Remize, F., 2013. Thermophilic spore-forming bacteria isolated from spoiled canned food and their heat resistance. Results of a French ten-year survey. Int. J. Food Microbiol. 165, 134-143.

Ashton, D., Bernard, D., 1992. Thermophilic anaerobic sporeformers. In: Vanderzantz, C. Splittstoesser, D.F. (Eds.), Compendium of Methods for the Microbiological Examination of Foods, 3rd edition American Public Health Association, Washington, D.C., pp. 309-316.

Byrer, D.E., Rainey, F.A., Wiegel, J., 2000. Novel strains of Moorella thermoacetica form unusually heat-resistant spores. Arch. Microbiol. 174, 334-339.

Carlier, J.-P., Bedora-Faure, M., 2006. Phenotypic and genotypic characterization of some Moorella sp. strains isolated from canned foods. Syst. Appl. Microbiol. 29, 581-588.

Carlier, J.-P., Bonne, I., Bedora-Faure, M., 2006. Isolation from canned foods of a novel Thermoanaerobacter species phylogenetically related to Thermoanaerobacter mathranii (Larsen 1997): emendation of the species description and proposal of Thermoanaerobacter mathranii subsp. Alimentarius subsp. nov. Anaerobe 12, 153-159.

Carlin, F., 2011. Origin of bacterial spores contaminating foods. Food Microbiol. 28 $177-182$.

Collins, M.D., Lawson, P.A., Willems, A., Cordoba, J.J., Fernandezgarayzabal, J., Garcia, P. Cai, J., Hippe, H., Farrow, J.A.E., 1994. The phylogeny of the genus Clostridium proposal of 5 new genera and 11 new species combinations. Int. J. Syst. Bacteriol. $44,812-826$.

Coorevits, A., Dinsdale, A.E., Halket, G., Lebbe, L., De Vos, P., Van Landschoot, A., Logan, N.A., 2012. Taxonomic revision of the genus Geobacillus: emendation of Geobacillus, G. stearothermophilus, G. jurassicus, G. toebii, G. thermodenitrificans and G. thermoglucosidans (nom. corrig., formerly 'thermoglucosidasius'); transfer of Bacillus thermantarcticus to the genus as G. thermantarcticus comb. nov.; proposal of Caldibacillus debilis gen. nov, comb. nov.; transfer of G. tepidamans to Anoxybacillus as A. tepidamans comb. nov.; and proposal of Anoxybacillus caldiproteolyticus sp. nov. Int. J. Syst. Evol. Microbiol. 62, 1470-1485.

Dhakal, R., Chauhan, K, Seale, R.B., Deeth, H.C., Pillidge, CJ., Powell, I.B., Craven, H, Turner, M.S., 2013. Genotyping of dairy Bacillus licheniformis isolates by high resolution melt analysis of multiple variable number tandem repeat loci. Food Microbiol. 34, 344-351.

Dotzauer, C, Ehrmann, M, Vogel, R., 2002. Occurrence and detection of Thermoanaerobacterium and Thermoanaerobacter in canned food. Food Technol. Biotechnol. 40, 21-26. 
Durand, L., Planchon, S., Guinebretiere, M.-H., Carlin, F., Remize, F., 2014. Genotypic and phenotypic characterization of foodborne Geobacillus stearothermophilus. Food Microbiol. http://dx.doi.org/10.1016/j.fm.2014.01.015.

Feeherry, FE, Munsey, D.T., Rowley, D.B, 1987. Thermal inactivation and injury of Bacillus stearotherophilus spores. Appl. Environ. Microbiol. 53, 365-370.

Feig, S., Stersky, A.K., 1981. Characterization of a heat-resistant strain of Bacillus coagulans isolated from cream style canned corn. J. Food Sci. 46, 135-137.

Fleiss, J.L., Levin, B., Paik, M.C., 2004. The Comparison of Proportions from Several Independent Samples, Statistical Methods for Rates and Proportions. John Wiley \& Sons, Inc., Hoboken, NJ, USA, pp. 187-233.

Fontaine, F.E, Peterson, W.H., McCoy, E., Johnson, M.J., Ritter, G.J., 1942. A new type of glucose fermentation by Clostridium thermoaceticum. J. Bacteriol. 43, 701-715.

Groenewald, W.H., Gouws, P.A., Witthuhn, R.C., 2009. Isolation, identification and typification of Alicydobacillus acidoterrestris and Alicyclobacillus acidocaldarius strains from orchard soil and the fruit processing environment in South Africa. Food Microbiol. $26,71-76$.

Guinebretiere, M., Nguyen-The, C., 2003. Sources of Bacillus cereus contamination in a pasteurized zucchini puree processing line, differentiated by two PCR-based methods. FEMS Microbiol. Ecol. 43, 207-215.

Guinebretiere, M, Girardin, H, Dargaignaratz, C., Carlin, F., Nguyen-The, C, 2003. Contamination flows of Bacillus cereus and spore-forming aerobic bacteria in a cooked, pasteurized and chilled zucchini purée processing line. Int. J. Food Microbiol. 82, 223-232.

Hornung, R.W., Reed, L.D., 1990. Estimation of average concentration in the presence of nondetectable values. Appl. Occup. Environ. Hyg. 5, 46-51.

Logan, N.A., De Vos, P. 2009. Genus I. Bacillus Cohn 1872, 174 AL. In: De Vos, P., Garrity, G.M., Jones, D., Krieg, N.R., Ludwig, W., Rainey, F.A., Schleifer, K.H., Whitman, W.B. (Eds.), Bergey's Manual of Systematic Bacteriology, Second edition . The Firmicutes Vol. Three, Springer, Dordrecht, pp. 21-128.

Matsuda, N., Masuda, H., Komaki, M., Matsumoto, N., 1982. Thermophilic, spore-forming. strict anaerobes isolated from spoiled canned "Shiruko" and coffee containing milk J. Food Hyg. Soc. Jpn. 23, 480-486.

Parkar, S.G., Flint, S.H., Palmer, J.S., Brooks, J.D., 2001. Factors influencing attachment of thermophilic Bacilli to stainless steel. J. Appl. Microbiol. 90, 901-908.

Periago, P.M., Fernandez, P.S., Salmeron, M.C., Martinez, A., 1998. Predictive model to describe the combined effect of $\mathrm{pH}$ and $\mathrm{NaC}$ on apparent heat resistance of Bacillus stearothemophilus. Int. J. Food Microbiol. 44, 21-30.
Postollec, F., Mathot, A.-G, Bernard, M., Divanac'h, M.-L, Pavan, S, Sohier, D.l, 2012 Tracking spore-forming bacteria in food: from natural biodiversity to selection by processes. Int. J. Food Microbiol. 158, 1-8.

Prevost, S., André, S., Remize, F., 2010. PCR detection of thermophilic spore-forming bacteria involved in canned food spoilage. Curr. Microbiol. 61, 525-533.

Raso, J., Palop, A. Bayarte, M., Condón, S., Sala, F.J., 1995. Influence of sporulation temperature on the heat resistance of a strain of Bacillus licheniformis (Spanish Type Culture Collection 4523). Food Microbiol. 12, 357-361.

Rigaux, C., André, S., Albert, I., Carlin, F., 2014. Quantitative assessment of the risk of microbial spoilage in foods. Prediction of non-stability at $55^{\circ} \mathrm{C}$ caused by Geobacillus stearothermophilus in canned green beans. Int. J. Food Microbiol. 171, 119-128.

Sànchez, B., Arias, S., Chaignepain, S., Denayrolles, M., Schmitter, J.M., Bressollier, P Urdaci, M.C., 2009. Identification of surface proteins involved in the adhesion of a probiotic Bacillus cereus strain to mucin and fibronectin. Microbiology 155, 1708-1716.

Scott, S.A., Brooks, J.D, Rakonjac, J., Walker, K.M.R., Flint, S.H., 2007. The formation of thermophilic spores during the manufacture of whole milk powder. Int. J. Dairy Technol. 60, 109-117.

Seale, R.B., Flint, S.H., McQuillan, AJ., Bremer, PJ., 2008. Recovery of spores from thermophilic dairy bacilli and effects of their surface characteristics on attachment to different surfaces. Appl. Environ. Microbiol. 74, 731-737.

Seale, R.B., Dhakal, R., Chauhan, K., Craven, H.M., Deeth, H.C., Pillidge, C.J., Powell, I.B., Turner, M.S., 2012. Genotyping of present-day and historical Geobacillus species isolates from milk powders by high-resolution melt analysis of multiple variablenumber tandem-repeat loci. Appl. Environ. Microbiol. 78, 7090-7097.

Sevenier, V., Delannoy, S., André, S., Fach, P., Remize, F., 2012. Prevalence of Clostridium botulinum and thermophilic heat-resistant spores in raw carrots and green beans used in French canning industry. Int. J. Food Mirobiol. 155, 263-268.

Tauveron, G., Slomianny, C., Henry, C., Faille, C., 2006. Variability among Bacillus cereus strains in spore surface properties and influence on their ability to contaminate food surface equipment. Int. J. Food Microbiol. 110, 254-262.

Wiegel, J., 2009. Genus VI. Moorella Collins, Lawson, Willems, Cordoba, FernandezGarayzabal, Garcia, Hippe and Farrow 1994, 822 $2^{\mathrm{VP}}$. In: De Vos, P., Garrity, G.M., Jones, D., Krieg, N.R., Ludwig, W., Rainey, F.A., Schleifer, K.H., Whitman, W.B. (Eds.), Bergey's Manual of Systematic Bacteriology, Second edition. The Firmicutes Vol. Three. Springer, Dordrecht, pp. 1247-1252.

Zeigler, D.R, 2014. The Geobacillus paradox: why is a thermophilic bacterial genus so prevalent on a mesophilic planet? Microbiology 160, 1-11. 